\title{
Non-verbal Communication and Communicative Understanding of the Liturgy and Liturgical Signs in the Light of Charles Sanders Peirce's Theory of Signs
}

\begin{abstract}
The human person as a "triadic" creature needs ritual at all three levels - physical, psychological and spiritual - of his or her being. At the physical level, ritual serves as support for a healthier life-style. At the psychological level, ritual regulates intrapersonal and interpersonal communicatio. At the level of spirituality, it places him or her in the context of transcendence and "recent aims" and both individually and communally gives meaning to human life. Therefore, the author of the paper first This paper starts by considering the human person as a ritual creature that already with his body requires certain ritual acts and various forms of nonverbal communication. In the central part of the discussion, the author focuses on Peirce's theory of signs and presents it as one model suitable for understanding and explaining liturgical signs. This is an interesting understanding of religious signs, which encourages an interpretative relationship between the human person and the liturgy, its signs and contents.
\end{abstract}

\section{Keywords}

Ritual, Rites, Liturgy, non-verbal Communication, Liturgical Signs - Symbols, Peirce's Theory of Signs, Spirituality.

Charles Sanders Peirce's theory of signs argues that all forms of thought depend on the use of signs ${ }^{1}$. In his opinion, every thought is a sign and

1 Charles Sanders Peirce (1839-1914) is generally regarded as the founder of American pragmatism, and, with Ferdinand de Saussure, of modern semeiotic - general theory of signs; he is known as a philosopher and theorist of logic; being at the same time a scientist he was an influential and polymathic thinker. Pierce identifies the theory of cognition with semiotics: for him the process 
every action of thinking is composed of an interpretations of signs that act as mediators between the external world of objects and the inner world of ideas. Indeed, signs may be mental representations of objects, while objects can be distinguished through their perception of signs ${ }^{2}$. "A sign, or representamen, is something which stands to somebody for something in some respect or capacity. It addresses somebody, that is, creates in the mind of that person an equivalent sign, or perhaps a more developed sign. The sign which it creates I call the interpretant of the first sign. The sign stands for something, its object"'s.

The first reason, which leads us to the use and interpretation of this theory, is that it is not imagined only as a process of thinking and communication at the level of language. It also includes non-verbal communication just as Peirce's semiotics embrace interpersonal communication in the broadest sense of the word (that is body language, movement, gestures, signs, and language) ${ }^{4}$. This means that when the method of semiotics is applied, it is largely engaged to preverbal communication. In the history of human communication, non-verbal communication is much older than verbal communication and, by its simplicity, more primal. An example, here would be an interesting phenomenon in Slovenia: on Easter Saturday at the blessing of the Easter food, more people assemble together than on any other holiday throughout the ecclesiastical year. This clearly indicates that food or nutrition, in relation to the spiritual dimension of life, is a more primal form of communication than language in the sense of verbalized words.

of logical reasoning is intrinsically linked to the world of signs. The root of the semiotic theory of Pierce is in fact philosophical and gnoseological; he declares an absolute equivalence between the process of cognition and signal inference. The objects of intellect - thoughts are considered as representations or symbols; logic is based on the reference of symbols to their objects. See L.R. Fabbrichesi, Introduzione a Peirce, Roma-Bari 1993, p. 12. He declares that we do not have any capacity to think without signs. The human thinking is necessarily inferential: there are three modes of thinking: deduction, induction and abduction. See S. Traini, Le due vie della semiotica: Teorie strutturali e interpretative, Milano 2006, p. 216-227. Nevertheless, for Peirce there is only one form of thinking, namely the one that realizes itself through the signs: thinking without signs does not exist. Ibidem, p. 218.

2 See C.S. Peirce, Izbrani spisi o teoriji znaka in pomena ter pragmaticizmu, Ljubljana 2004, Krtina, p. 10.

3 A. Baicchi, Signs and Semiotics, in: C. Siobhan, C. Routledge (ed), Key ideas in Linguistics and the Philosophy of Language, Edinburgh 2009, Edinburgh University Press, p. 207-208.

4 See H. Graham, Worship as Meaning. A Liturgical Theology for Late Modernity, Cambridge 2003, University Press, p. 123-134. 


\section{The Body Needs Rites}

The loss of sense of values and relationships, lack of exercise, and neglect of ritual dimensions are the three key factors that trigger the malaise of the modern human person. It is interesting that the liturgy has through the whole tradition interwoven all of these three factors. In this way, it advocates a healthy lifestyle. For today's ailments, often interpreted as the result of an unhealthy diet, no quick remedy is found even in a world that has witnessed the most complex technical and biological improvements. On the contrary, it could be found in the inner transformation of the concept of life, which includes the whole system of values and the rehabilitation of relations, also including the spiritual dimension of life ${ }^{5}$.

Statistical information on the growing number of obese people not only points to a lack of movement, but also a loss of sense of ceremony and ritual, and the capacity for spiritual communication. Prayer before and after meal, for example, is both ritual and communication, which the body needs as it prepares for the ingestion of healthy food in the correct quantity. At the same time, both Christian and Jewish traditions integrate a healthy meal on a regular basis in the context of religious and anthropological communication. Indeed, the human person is at the basis of ceremonies, necessary for a healthy life $\mathrm{f}^{6}$.

The need for ritual can also be observed in sports, where the body should be at the centre. It is not just about the fact that sports in the beginning, especially in the Greek tradition, were "God's work", as the intention of athletes was imbued with the desire to be as close to the gods as possible and become similar to them ${ }^{7}$. The Greeks actually called the Olympic Games "panegyrics", which indicates more a "celebration" than a competition. The entire celebration, including the demand for peace between games, had a very prominent liturgical character ${ }^{8}$. On this basis of Greek tradition, the founder of the Olympic Games of the modern era put the religious dimension at the

5 J. Musek, Duhovna kriza, vrednote in psihologija, »Psihološka obzorja - Horizons of psychology« 3-4 (1993), p. 124.

6 See A. Crnčević, I. Šaško, Na vrelu liturgie. Teološka polazišta za novost slavljenja i življenja vjere, Zagreb 2009, Verbum, p. 79-80.

7 A. Koch, Die Leibesübungen im Urteil der antiken und frühchristlichen Anthropologie, Schorndorf bei Stuttgart 1965, Hofmann Verlag, p. 23.

8 B.J. Bickel, Sport und Religion, Recklingshausen 1960, Mertens, p. 18. 
centre $^{9}$, which in its ritual dynamics still represents a unique, albeit profaned, application of Catholic worship. Many athletes before competition perform a specific ritual (often religious in nature), which is required by the body and not merely by the "soul". Some may perform such a ritual more routinely than consciously, but even in that case it achieves its purpose only when it grows from healthy spiritual roots. Religious ritual without a theological spiritual dimension verbalized by the human person in his or her culture, would be recognized by the body as a foreign entity, which destroys the harmony between body, movement and word ${ }^{10}$. At the same time, the body contains all "elements" that are necessary to experience the sacramentality of liturgical rites along with an appropriate spiritual preparation ${ }^{11}$.

In rituals as a way of life one undoubtedly includes morning prayer, hymns and vespers. Their informative value lies not only in direct religious communication with God, but also in their ability, as rituals, to activate the body in the morning and calm it in the evening. It is true that prayer at the level of ceremony "speaks" only if it is genuine and deep. The body is "smart", it does not lie, and it will not allow being deceived ${ }^{12}$. It always expresses itself directly and in accordance with the principle of the "here and now"13.

Of a similar symbolic role, one could mention the playing of bells. These wake people in the morning and invite them to prayer or worship. They call them again at noon for prayer and lunch and once again in the evening to prepare the body and mind to rest.

\section{Body and non-Verbal Communication in the Liturgy}

Non-verbal communication is not only more primal than verbal communication, but it is also richer in content. According to published research, more than $65 \%$ of human messages depend on $\mathrm{it}^{14}$. In particular, non-verbal

\footnotetext{
9 See P. De Coubertin, The Olympic Idea, Stuttgart 1967, Karl Hofmann, p. 107-110.

${ }^{10}$ See A. Pease, Govorica telesa, Ljubljana 1996, Mladinska knjiga, p. 20.

${ }^{11}$ A. Crnčević A., I. Šaško, Na vrelu liturgie ..., op. cit., p. 82.

${ }^{12}$ See M. Rush, Decoding the secret language of your body, New York 1994, Fireside, p. 23.

${ }^{13}$ T. Lamovec, Načela gestalt terapije za vsakdanje življenje II, Ljubljana 1997, ARX, p. 7.

${ }^{14}$ See A. Pease, Govorica..., op. cit., p. 10.
} 
communication is important for substantiating verbalized contents ${ }^{15}$. Only in the harmony between body attitudes, movements and spoken words that human persons impregnate their communication with the necessary amount of emotional dimensions, which changes the process of communication to "art"16. In liturgical actions, this art in relation to space and ritual is even more important to achieve an equilibrated expression. The religious attitude captures "the whole person"

Unlike other creatures, the human person has, metaphorically speaking, a shape of a cross. The human body has the ability to keep straight in an upright position with extended arms and hence forming the shape of the cross.

One quickly notices that there is perfect harmony and balance in forming such shape. It represents the perfect unity between the vertical and the horizontal. Apart from the genitals, all vital organs for life are located in the upper part of the body. In this part, people think, feel, and digest. All these organs are carried by the back, hence it is understandable that the traditions formed sayings, which also relate to the ethical and moral dimension of life. Because of his or her upright position, the human person is recognized as a morally responsible being, who in forming the cross joins apparent contradictions that, without the cross - both symbolic and completely practical - would not be connected: above and below, heaven and earth, light and darkness, life and death ${ }^{18}$. It is the ability to connect these opposites that leads the human person throughout its life to discover an integrated personality ${ }^{19}$. The apostle Paul expresses this in his First Letter to the Corinthians when he says: "For the message of the cross is foolishness to those who are perishing, but to us who are being saved it is the power of God"20. In this context, the path to the Christian understanding of the

${ }^{15}$ M. Paladin, Neverbalna komunikacija: Dopolniti besede in biti preprečljiv, Nova Gorica 2011, Educa, Melior, p. 73.

${ }_{16}$ B. Kroflič, Ustvarjanje skozi gib, Ljubljana 1992, Znanstveno in publicistično središče, p. $14-15$.

17 A. Stres, Človek in njegov Bog, Celje 2007, Mohorjeva družba, p. 14.

${ }_{18}$ See E. Bihler, Symbole des Lebens - Symbole des Glaubens II. Limburg 1994, Lahn-Verlag, p. 240.

${ }^{19}$ S. Gerjolj, Živeti, delati, ljubiti, Celje 2009, Celjska Mohorjeva družba, p. 159.

201 Corinthians 1:18. The Apostle Paul connects "salvation" and "damnation" with the decision for Christ. Broadly speaking, the way to "ruin" is lead by the inability of integration of opposites, which, particularly in so-called Western civilization, is illustrated by common examples of apathy, depression, and even suicide. 
cross, which in Christ symbolizes (resurrection) life, happiness and joy; as well as death, suffering and pain, it reveals an open and transcendent reality. In connection to Christian anthropology, standing can be linked to a fundamental religious and devotional attitude ${ }^{21}$. On the one hand, it indicates human uprightness and independence, but on the other hand it also reflects the continuing request to God to be supported and preserved in this attitude $^{22}$. It includes participation at the resurrection in "the grace in which we stand" 23 , the fullness of which will be achieved in heaven ${ }^{24}$. Standing is the posture that represents Christ's victory over sin and death and connects us with the Risen Christ ${ }^{25}$.

The theological and anthropological dimension of a gesture is even more obvious when make the sign of the cross with our spread arms. Already the introductory procession in mass or the initial greeting gives meaning to the standing posture when the priest "automatically" spreads out his hands, and places his entire body in the shape of a cross, a prominent posture for open, direct, honest and authentic communication. All the senses used for communication are located at the front of the body - the "cross". The cross with spread hands is the most convincing posture of communication and is the starting point for a hug, be it in pain or in joy. With open palms facing upwards, it expresses confidence and courage ${ }^{26}$, as well as honesty and consistency with the spoken word ${ }^{27}$.

According to Christian liturgical tradition, we spread out our hands in particular in relation to the joyous message which in the Eucharistic sacrifice reaches a kind of climax in the greeting of peace. In some cultures, this

${ }^{21}$ See I. Platovnjak, J. Roblek, Moliti s telesom, dušo in duhom: Molitveni priročnik, Ljubljana 2011, Župnijski zavod Dravlje, p. 44.

221 Cor 16:13.

${ }^{23}$ Romans 5:2; Revelation 7:9, 15:2.

${ }^{24}$ Revelation 7:9, 15:2.

${ }^{25}$ I. Šaško, Per signa sensibilia: liturgijski simbolički govor, Zagreb 2005, Glas Koncila, p. 82.

${ }^{26}$ Moses' victory in the battle with the Amalekites, who can symbolize everything that distracts us from God and is life-threatening. See S. Gerjolj, Živeti..., op. cit., p. 298-300. Also depends on his spread arms. See Exodus 17:8 to 13. It is interesting that after Moses' hands fall, Aaron and Hur approach and support him in the original posture of prayer, hope and courage. In this example, we can immagine the role and power of personal or individual and community prayer.

${ }^{27}$ See A. Pease, Govorica..., op. cit., p. 23. 
greeting is also expressed in the form of a hug and a kiss. In both cases, the liturgical gesture leads to touch that one can experience at the level of physical and transcendent communication ${ }^{28}$. All of this points to the fact that the human person, in addition to being a "(religious) being of ceremony", is also a communal being. It is in this dimension that he or she is included in the events of salvation by liturgical rites ${ }^{29}$, which historically often recommend standing prayer with open $\operatorname{arms}^{30}$.

In addition to that basic Christian posture, the liturgical rite incorporates other body postures and gestures, which harmonize the body with spiritual events. One such position, sitting, prepares the human person for listening, thinking and meditation, as well as for speech and conversation. Usually people dine and talk in a sitting position; with this posture people acknowledge that they are making time for the other person and that they want to listen or talk to the other person without time pressures. The Last Supper probably did not take place standing up, Lazarus's sister Mary was sitting at Jesus' feet ${ }^{31}$, and while teaching, Jesus often commanded his listeners to sit $^{32}$. Slightly less domesticated in the Christian tradition is kneeling, which is intended either for a more personal prayer or a moment in the liturgy, which at the level of intrapsychic communication highlights the sinfulness and smallness of the human person or community before God. This dimension of life is further underpinned by tapping the chest ${ }^{33}$, which also illustrates the parable of the tax collector that "beat his chest, saying, 'God, be merciful to me a sinner!'“34.

Different postures and gestures thus illustrate how the dynamics of salvation take place not only on a symbolic level, but also address the whole person, including the body, and are actually incarnated in the ritual experience ${ }^{35}$.

\footnotetext{
${ }^{28}$ Some researchers of non-verbal communication identify the transcendent level of communication in movement and in touch outside the immediate religious context, particularly in dance. See M. Zagorc, Ustvarjalno gibalna improvizacija, Ljubljana 2008, p. 85.

${ }^{29}$ Matthew 18:20; Sacrosanctum Concilium 7.

${ }^{30}$ M. Künzler, Liturgia Kościoła, Poznań 1999, AMATECA, p. 181.

${ }^{31}$ Luke 10:39.

${ }^{32}$ Mark 3:32.

${ }^{33}$ See I. Šaško, Per signa..., op. cit., p. 92.

${ }^{34}$ Luke 18:13.

35 Sacrosanctum Concilium 48.
} 


\section{Peirce's Theory of Signs with Three Phenomenological Categories}

Pierce's understanding of the sign consists of three components. There is first what he calls the "representamen" that is the exterior sign, the object which the sign stands for (the semiotic object) and the "interpretant". The second component is the reality expressed by the sign, the entity to which the sign relates. The third component of the sign is its meaning. The interpretant relates to and mediates between the representamen and the semiotic object in such a way as to bring about an interrelation between them at the same time. In the same way, it brings itself into interrelation with them ${ }^{36}$. The representamen directs one's attention to the semiotic object, then one (the interpretant) gets some sort of meaning ${ }^{37}$.

Peirce believes that each entity acts as a sign. He tries to consider all entities through three phenomenological categories: "Firstness", "Secondness" and "Thirdness". Each of the categories dominates a specified field of thinking. Firstness belongs to quality. Secondness focuses on the existential experience. Thirdness refers to mediation or interpretability. Peirce says that the sign functions through the triadic relation between the three categories: Firstness stands in such a genuine relation with Secondness, called its object, that it is able to determine Thirdness, called its interpretant ${ }^{38}$.

Firstness is the form of being that is free of any referring to any entity or object, it is therefore pure quality and pure possibility, whose relationship to the material (substance) is random. All entities in the virtue of Secondness actually exist and lead to something that they themselves are not. Entities may be Firstness only as long as they are not embodied, until they do not become a matter of individual or singular event. The category of Secondness is, according to Peirce, a category of individuality and in fact existing. Secondness is therefore a form of being, which refers to any object or entity.

${ }^{36}$ F. Merrel, Charles Sanders Peirce's Concept of the Sign, in: P. Cobley (ed), The Routledge Companion to Semiotics and Linguistics, London-New York 2001, Routledge, p. 28.

${ }^{37}$ F. Merrel, Charles Sanders Peirce's Concept of the Sign, op. cit., p. 29.

${ }^{38}$ C. S. Peirce, Izbrani spisi ..., op. cit., p. 11. Signs become meaningful in the process of semiosis which goes from feeling, sensation, and experience through the conceptualization of sign. Since sign processing from feeling, sensation, experience and conceptualization, is just that, a process, signs can have no determinable and self ordained closure. See F. Merrel, Charles Sanders Peirce's Concept..., op. cit., p. 32. "The categories in this manner might be considered tendencies rather than forms, conditions of becoming rather than static signs attached to things". F. Merrel, Charles Sanders Peirce's Concept..., op. cit. 
Thirdness is a form of being that combines Firstness and Secondness in a mutual relationship and mediates between them. Thirdness is the form or way in which signs exist, through mediation or intervention between objects and their interpretant.

Firstness can be expressed as quality, a feeling or sensation, freedom and diversity. Secondness can be expressed in terms of action, reaction, causality, reality, actuality and concreteness. Thirdness is represented through the presentation of thoughts, continuity, order, unity and universality. Thirdness has no Secondness or Thirdness (it is pure chance), but Secondness and Thirdness have their own Firstness. Firstness is the form of being, quality but not relationship. Firstness is an option, Secondness is the materialized form of existence of a certain quality and Thirdness is a form of existence of the sign or representation of the sign ${ }^{39}$.

When people talk about God's presence and his activity they are delving in mystery. The human person could not come to experience this mystery if there would not be revelation or a direct experience of God. In the history of religions and the Old Testament, there are descriptions of the human experience of secrets ${ }^{40}$. These records or accounts of the experience of God are situated on the level of Thirdness and are already a kind of interpretation of this experience. The vocabulary and elements of language which are used by descriptions are situated on the level of Secondness that is the level of human existence and experience. If there were not this existence and experience then people would not be talking about God's mystery, which is at the level of opportunities and pure freedom - of Firstness. The liturgical experience is the experience of mystery, and mystery is on the level of Firstness. Life experiences and elements (signs or characters) are taken out of the dimension of life, which belongs to the level of Secondness, the

39 J. Justin, Uvod v Peirceovo teorijo znaka in pomena, in: C. S. Peirce, Izbrani spisi..., op. cit., p. 172-175. Firstness: what there is, such as it is without reference or relation to anything else. Secondness: what there is such as it is, in relation to something else, but without relation to any third entity. Thirdness: what there is such as it is, insofar as it is capable of bringing a second entity into relation with a first one and itself into relation with each of them. See F. Merrel, Charles Sanders Peirce's Concept..., op. cit., p. 32. Red colour in itself is just a feeling, an experience of eyes (Firstness). When we see red colour in the semaphore it has a meaning; there is a relationship between the colour and the light (Secondness). "It is a matter of something actualized in the manner of this happening here, now, for some contemplator of the sign". Ibidem, p. 33. We understand the red light as warning (should be), and we stop (Thirdness).

40 Jacob's ladder, Genesis 28:10-19, etc. 
realization of liturgy, which is also the interpretation of the mystery, and is the level of Thirdness.

\section{Liturgical Signs in the Light of Peirce's Triadic Distribution of Signs}

Charles Sanders Peirce defines a sign as something that represents a specific content or a particular meaning. A sign is something that represents a certain reality be it a physical object, event or idea. However, the sign (and the meaning it conveys) does not exist unless there is someone who receives the sign and interprets it. For Peirce, in contrast to Saussure, who considered the sign on the basis of a dyadic composition (signifiant - signifier, signifié - signified), the sign has a triadic structure. Peirce, in addition to the signifier and the signified, includes the interpretant. According to him, a sign is addressed to someone, which means that in the mind of the person who receives the exterior form of the sign it is supposed to create the same content (message) as it has for the sender of the sign, or to cause it to have a broader meaning (a more developed sign) ${ }^{41}$. This can be applied to liturgical signs and gestures as follows.

A certain gesture, for example the celebrant spreading his hands with the exclamation the Lord may be with you, is something that has meaning for the community just because it is an agreed and understood sign in the framework of a certain practice. If there would be a non-Christian in Church and unsurprisingly unfamiliar of the Christian liturgy, this sign would have no meaning and possibly eliciting a completely different response.

This theory emphasizes the fact that the recipient of a particular message, co-creates the meaning of the signs, in such a way that he or she recognizes at first the signs that convey a message which is supposed to be understood and interpreted. This assumes that the receiver of message is introduced to the understanding and the use of signs or symbols.

At the practical level, it means that for worship it is vital that its language is understood. It is important also that every participant enriches the liturgy by his or her presence and participation. Of course, this cannot be an exaggerated disclosure of human internal states and feelings. Rather, it is about the awareness of human existence with respect for each individual's life situation

\footnotetext{
${ }^{41}$ See C. S. Peirce, Izbrani spisi ..., op. cit., p. 10.
} 
in which he or she pursues salvation through liturgical action. By the divine presence, liturgy is supposed to enrich the experience of life of those who co-celebrate in the liturgy and inject quality to their everyday life-reality by means of faith.

First of all, this theory points out the role of the worship leader and that it is necessary to experience and celebrate the liturgy as a unique event, always as a new and unrepeatible event, as the Psalmist says: "Sing to the Lord a new song!"42. The new song has neither a new text nor a new tune, but rather a new spirit and keenness, a new experience and a broadened life before God. This means that the priest, with his personal style of celebration "in spirit and truth" Otherwise he may discourage people from participating in the liturgy or block their understanding the mystery of the liturgical action. It is enough if one just thinks of how the priest pronounces the words of consecration, or how he holds the consecrated host and cup, or how he kneels. His attitude of participation at Christ's sacrifice should reflect the mystery that is celebrated on the altar.

Thus, Peirce's theory could be very useful for the interpretation of liturgical signs, as it adds a third category - the interpretation (Thirdness), which on the one hand means the conveyed communication and on the other hand, the role of the receiver, who interprets the content of the message and arrives at a meaning. Indeed, in the process of communication there is someone who emits signs, so that he or she creates its material form, and through a concrete form communicates the meaning. On the other hand, there is the recipient of a message who recognizes the physical appearance of signs and through this concrete form perceives the meaning that he interprets at the same time. According to Peirce, this content of sign(s), in the light of Thirdness, is called the interpretant.

In liturgy, this means that the leader of the worship is the one who is emitting signs (symbols), after he has taken them from the treasure of liturgy, adopted and internalized them. This means that he is a recipient too and at the same time the one who interprets, thus he creates the interpretant (vivid content). On the other hand, the faithful, who are involved in liturgy and who by means of the leader receive the message of God's presence, which had been already interpreted by the celebrant, are the ones who interpret it in their turn for their life in faith.

\footnotetext{
42 Psalms 98:1.

43 John 4:24.
} 


\section{Liturgical Understanding of Signs in the Light of Peirce's Division of Signs regarding the Relation of the Sign to its Object}

Peirce divides signs into "iconical" signs, indexical signs and symbols, depending on the nature of their relationship to the object or content that they represent. What follows is a presention of these three types of signs by finding them in the liturgy and interpreting them with the help of their function.

5.1. In iconic signs there is a relationship of similarity or parallelism between the sign as an instrument and its meaning. Everything is an icon of something, as long as it is like this thing and is used as its symbol. Iconic signs are also marked by Firstness (an idea which has to produce an interpreting idea - similarity). This can be shown in the following examples: the icon on the computer; photo or picture can be identified as a picture of what it represents. A photo is similar to the object that it represents. This means a sign-holder (picture) and its object, what a picture presents, share a common particular feature. This fact that they have a common feature is the similarity between them, but this similarity allows an object or reality to represent some other object or another reality ${ }^{44}$.

Likewise in the liturgy, signs operate on the basis of similarity or parallelism and metaphors. For example, a procession is a liturgical event having its original archetype in the exodus of Egypt, but it represents the pilgrim Church. If one compares the exodus from Egypt and the liturgical procession, one sees that the two are similar in overcoming the distance that was experienced by the people of Israel, yet at the same time it is the reality of the pilgrim Church today, expressed by a symbolic liturgical act.

There is a similarity between iconic and liturgical signs. This is the reason why iconic signs can be applied to the liturgy. If one takes, for example, an icon, one sees that it is a symbolic representation that expresses similarity with Christ, Mary, and the saints. In everyday life, a burning candle can be used as a source of light; but in the ecclesial context or in the course of the paschal liturgy, it signifies that Christ is risen from the dead and is present in the life of believers. A small light may indicate that the Sacrament of Christ's body is in the tabernacle. Water, universally used for the preservation of physical life, in the context of baptism signifies life in Christ. Deep waters are dangerous and are presented as a place of death. In the same way, the

\footnotetext{
${ }^{44}$ See H. Graham, Worship..., op. cit., p. 140; C. S. Peirce, Izbrani spisi..., op. cit., p. 16-19.
} 
waters of baptism signify the place of death, into which Christ entered to save humanity. Through faith in Christ's resurrection, baptismal water is a source of everlasting life. Water also has the function of cleaning the human body. In the liturgy of baptism, water represents the purification of the human being.

In the liturgy, iconic signs can also play the role of 'indexical' signs and symbols. This means that liturgical signs do not function only on the principle of similarity, but also as indexes and symbols. An example of a sign having a double meaning is the place of worship. On the one hand, it is an iconic sign; that is to say, it defines the sacred place on the principle of parallelism because it separates it from the secular, profane. At the same time, it is also a symbolic sign of communion, unity, and a gathering in $\operatorname{God}^{45}$. Similarly, liturgical time exists as an iconic sign; it acts on the basis of parallelism with secular time. It is about the beginning and the end of a particular period. It concerns the duration of time. Simultaneously, it is a symbolical sign, because it is based on the principle of convention.

Liturgical celebration in itself is linked to the category of time. As in every event, there is a beginning, with a duration and an end. In this sense, liturgical celebration is 'iconical'. At the same time, liturgical celebration acts on a symbolic level as kairos - consecrated time. For example, by consecrating the chalice of the Passover meal at the beginning of the ritual, the head of the family set apart the time of the celebration of the Passover, dedicating it to the worship of God. Any liturgical act of consecration is a devotion of time and of the participants to worship. People participate in a liturgical event that that have entered and we co-create it. Every liturgy is happening as a sequence of events that are arranged according to a predetermined plan. In faith we experience events of salvation. In every liturgical celebration in fact, we enter into narrative, a story that begins, has its peak, is concluded, and then we leave it at its ending. The main feature of this story is the transformation. Salvation in Christ brings about radical change in the human situation, just as any liturgical event similarily should cause change in the heart of those who participate in the liturgy.

The posture of standing or getting up is an iconic sign. Based on analogy it operates through its resemblance to a person who is alive. But at the symbolical level, it signifies the resurrection of Christ and new life for those who believe in him.

45 John 17,21 . 
5.2. Indexical signs or symbols are signs (evidence, impressions), where there exists a causal or natural relation between the means of the sign and its meaning: a fan shows the direction of the wind, because it is in a mechanical relation with the wind; knocking on a door is a sign that someone wants to enter; some signs on the body are symptoms of a disease; dark clouds are signs of a storm, etc. We can distinguish these signs from other signs in three ways. First - they have no semantic similarity with their contents or with the reality that they represent. Second - they refer to individuals, individual units, individual sets of units or individual events in sequence. Third - they focus our attention on objects that they represent in the way of blind force. This means that when someone sees smoke, we cannot infer anything else than fire. The relationship between the external sign and its object is the relationship of cause - effect $^{46}$.

These signs are not similar to that what they are because there is merely a causal or mechanical connection. For example, ringing indicates that there is a bell. Smoke indicates the existence of fire. Water is a sign of life (if there is no water there is no life). Bread is made of ground wheat and is also a sign of survival.

All signs of this kind have symbolic meaning in the context of liturgy. The ringing of a bell reminds us that the priest and altar servers are at the door of the sacristy, ready to start the celebration. In this sense, ringing is an indexical sign. At the same time, ringing means an invitation to attention and worship; in this sense ringing is a symbolical sign. Smelling incense tells us that the priest has placed it on the coals during the offertory (in case we don't see this because of the crowd); in a symbolic way, smelling incense expresses the desire that our prayer would rise up to God as incense; incense also means the quality of belonging to Christ. When we see bread, it reminds us of eating, necessary for life (natural relation); for someone else it may also recall the love of their mother, who used to make bread (indexical sign); bread on the altar (hosts) express Christ's love and his sacramental presence (symbolic value of the sign).

In the context of theoretical reasoning, all indexical meaning belongs to the category of Secondness. Our focus is to highlight the importance of signs and their language in the liturgy. How can liturgy become meaningful for

\footnotetext{
${ }^{46}$ H. Graham, Worship..., op. cit., p. 140-141; See C. S. Peirce, Izbrani spisi..., op. cit., p. 19-24.
} 
those who participate in it? The meaning of every liturgical celebration lies in the harmony of everything that the liturgy realizes through its actions, language and signs. Liturgy should meet us on the level of faith: it brings about the actualization of salvation. Liturgy becomes concrete on the level of Secondness, but an important question remains open: is the liturgy an act or event of blessing for those who participate in it and does it strengthen them spiritually?

The indexical sign is thus marked by Secondness, by direct factuality (reality). This should lead us to consider the relationship between what is celebrated in the liturgy and the reality of every day life. The indexical sign represents the subject according to the principle of causality. This principle could be transferred to the liturgy, not only on the level of operating of signs, but on the deepest level of faith where the sacraments make possible the real presence of Christ ex opere operato. Sacraments realize what they represent. Thus the matter of the sacrament of the Eucharist (bread and wine) points to the Cause which is the subject of the sacrament: it is Christ who realizes the sacrament through the action of the Holy Spirit by the means of its minister.

At the level of participation in the liturgy, it is important that its reality touches those who interpret it. The priest, by his spiritual life and preparation for the liturgical celebration, is supposed to let Christ act on him so that he might be more and more conformed to Christ, becoming a transparent sign of God's love for his people. This fact reveals to us once again the intrinsic relationship of cause and effect at the level of faith. Therefore, the question of indexical signs in the liturgy leads us to think about the role of the priest, cantors, and faithful and at the same time it warns us against the danger of ritualism and routines ${ }^{47}$.

5.3. Signs - symbols: Peirce considers that a symbol is a sign which would lose its characteristics that make it a sign if the interpretant is missing. The sign is connected with its object on the basis of a convention. An agreement exists between the emitter and receiver about the significance of the sign. "Words, the Morse code, algebraic signs are for the most part arbitrary in the beginning though in their practice they have become conventual customarily to respond along predetermined path ways" ${ }^{\prime 4}$. If

\footnotetext{
${ }^{47}$ See H. Graham, Worship..., op. cit., p. 170-176.

${ }^{48}$ F. Merrel, Charles Sanders Peirce's Concept..., op. cit., p. 38.
} 
there is a convention it means that also a receiver of signs is included. On one side, there is the emitter of a sign and on the other side, there is the receiver of the sign. For the concept of sign, Pierce also used the synonym representamen; it is something that represents another reality, regardless of what the sign is in itself. In the process of transmission and reception the sign-symbol generates an equivalent meaning, or meaning that may be more sophisticated, in the spirit of the receiver. The meaning that comes through in the mind of recipient is called the interpretant. The newness of Peirce's theory is this process, which enables a larger or deeper reality of meaning. According to Pierce, the interpretant is an information created in the mind of recipient, which mediates between the sign as means and its object as content and thus produces the meaning supposed to be hidden in the sign ${ }^{49}$.

If one transfers the argument of sign-symbols to the field of liturgy, one may see important implications of symbolical language for the sacraments. A case in point here is the wedding ritual. Somebody present at a wedding ceremony may find the sign of wrapping the hands with the stole strange, or of no importance. However, the human person who is getting married and has thought about his decision at that moment, realizes that he will be tied for his whole life. He may be deeply touched. This shows us that the newly-married man understands the sign in the conventional sense, and that he finds in it another meaning relative to his own experience. Peirce says that the sign should allow the one who receives and interprets it the possibility of grasping the meaning in his own way, according to the conditions of his own understanding and experience.

According to Peirce's triadic division of signs, symbols belong to the category of Thirdness, as this category implies an interpretation of signs. To this category belong also laws, customs, traditions, language, and, in short, everything that works at the level of interpretation of human experience and provokes the reaction between inner and outer reality.

${ }^{49}$ C. S. Peirce, Izbrani spisi ..., op. cit., p. 16, 24. Peirce's symbol is a linguistic sign whose interrelation with its semiotic object is conventual; that is to say that there is no necessary natural link, or a link due to some resemblance or similarity. F. Merrel, Charles Sanders Peirce's Concept..., op. cit., p. 31. Signs-symbols are not made and taken solely in terms of feelings and sensations nor by perception and inferential process nor by habitual actions and reactions. On the contrary, they must be learned by explicit instruction and practice. F. Merrel, Charles Sanders Peirce's Concept..., op. cit., p. 38. 
Every society is governed by laws that can be interpreted differently. For example, a lawyer will interpret a certain law differently than someone who has violated the same law. There are always different possible interpretations of the same law, depending on the experiences, situation and level of the person interpreting the law. Even in liturgy something similar happens: a professor of liturgy will interpret worship quite differently than a believer who participates at mass. According to the particularity of Peirce's theory, which can be applied to the liturgy, anyone who participates in the liturgy, interprets it in his own way and may add something of his own to its meaning.

When dealing with liturgical signs, they have to be interpreted using all three of Peirce's categories. The signs accomplish their function at the level of Thirdness, but also include Firstness and Secondness too. If one takes, for example, the sign of the cross (crucifix), one can, using the three categories, come to following conclusions:

(a) At its foundation, the sign of the cross works on the basis of similarity with the Crucified (historical Jesus) and in this sense it is an iconic sign. In this sign, the category of Firstness is the possibility (notion) of human suffering and death. Suffering in itself can happen in concrete situations of human experience. Death is real only when a person dies.

(b) In the Christian faith, the sign of the cross is the sign of redemption. On the basis of a cause-effect relationship, one can classify it as an indexical sign. We may think about the sign of the cross under the aspect of the category of Secondness; it is made possible by the causal link between the sign of the cross and the real crucifixion event. If there were no crucifixion, there would be no sign of the cross in historical sense.

(c) The sign of the cross (crucifix) is the symbol of Christianity. It is a symbol because it is something that Christians agree upon, arriving at this truth through instruction, learning and practice. These are the ways by which a sign becomes a symbol. Therefore, the sign of the cross operates on the basis of Thirdness, because it is a symbol. The cross as a means of punishment became a symbol on the basis of the experience of the crucifixion of Christ, as a means for remembering and announcing this historical event. The emitter, in the sense of sign, were the apostles who had a special role as missionaries, messengers of the resurrection. In addition, the receiver, all those who received the good news, interpreted it and gave testimony to Christ, some of them until death. Thus, we can see that the receivers of the good news are actively involved in interpreting the message while receiving it. This 
openness to the message of Christ allows them to enter into relationship with Christ and obtain salvation. When we touch the cross or make the sign of the cross in faith, it puts us in a situation between the possibility of salvation and the achievement of salvation.

In a nutshell, in view of the category of Thirdness, Peirce emphasizes the recipients' relationship to the message of the sign. He considers that a sign allows the recipient in some way to add to the meaning out of his own understanding or conception of the sign.

If one makes again the sign of the cross, seeing the crucifix allowes one to draw the conclusion that the cross might have been placed in a certain place along the road for personal reasons (maybe in thanks to God because the person was saved from death during the war). Placing this cross on high was his interpretation. When someone else is passing by the cross, he can interpret it in relation to what he carries in his own personal experience. It depends on his memories and experience or his faith. The cross may remind someone else of his youth or his suffering, or it may strengthen his faith and hope and at that moment, he can also strongly feel God's forgiveness. Therefore, everyone cocreates the reality of this or any other sign, according to his own interpretive potential. Something similar is seen in the celebration of a funeral or wedding mass. At the funeral mass, the person affected by the loss of his relative experiences the liturgy in his own way, taking into account everything that he lived. The mass in the context of a wedding becomes particularly relevant to the bride and groom.

Something should be said about the necessity of preparing for mass. Someone who reads the Word of God before Mass and asks himself if he or she is trying to live according to this word, certainly adds to the meaning of the liturgy for himself. Or someone who, during the sign of peace shakes hands with a neighbour with whom he has been at odds for many years, adds to the meaning of offering peace during the mass. The one who has been offered the hand of peace may be shocked as well and out of this sudden event he may experience this liturgy in a completely different way.

\section{Conclusion}

In light of Peirce's theory of signs we may affirm that signs and symbols constitute an integral part of any language, especially the language of 
worship. As there is no language without signs, there is no worship without signs and symbols. Another idea leads us to the importance of introduction for understanding liturgical signs and their appropriation by all who participate in the liturgy (especially with regard to the leader). The third and perhaps most important fact revealed to us by Peirce's theory, is the triadic structure of the sign or symbol. This study presupposes that in the process of semiosis the recipient of the signs should participate in parallel to the emitter. The recipient co-creates the meaning of the sign for his own understanding, while adding his own interpretation to the meaning or content of any sign or symbol, depending on how he received the sign.

\section{Bibliography}

Bickel B. J., Sport und Religion, Recklingshausen, Mertens 1960.

Bihler E., Symbole des Lebens - Symbole des Glaubens II, Limburg, Lahn-Verlag 1994.

Baicchi A., Signs and Semiotics, in: C. Siobhan, C. Routledge (eds.), Key ideas in Linguistics and the Philosophy of Language, Edinburgh, Edinburgh University Press 2009, p. 205-209.

Crnčević A., Šaško I., Na vrelu liturgie. Teološka polazišta za novost slavljenja i življenja vjere, Zagreb, Verbum 2009.

De Coubertin P., The Olympic Idea, Stuttgart, Karl Hofmann 1967.

Fabbrichesi L.R., Introduzione a Peirce, Roma-Bari, Editori Laterza 1993.

Gerjolj S., Šport in religija, in: D. Macura, M. D. Topič, B. Mekinda (eds.), Statusna vprašanja slovenskega športa, Ljubljana: Univerza v Ljubljani 2010, p. 43-53.

Gerjolj S., Živeti, delati, ljubiti, Celje, Celjska Mohorjeva družba 2009.

Graham H., Worship as Meaning. A Liturgical Theology for Late Modernity, Cambridge, University Press 2003.

Justin J., Uvod v Peirceovo teorijo znaka in pomena, in: C. S. Peirce, Izbrani spisi o teoriji znaka in pomena ter pragmaticizmu. Ljubljana, Krtina 2004.

Koch A., Die Leibesübungen im Urteil der antiken und frühchristlichen Anthropologie, Schorndorf bei Stuttgart, Hofmann Verlag 1965.

Kroflič B., Ustvarjanje skozi gib, Ljubljana, Znanstveno in publicistično središče 1992.

Künzler M., Liturgia Kościoła, Poznań, AMATECA 1999.

Lamovec T., Načela gestalt terapije za vsakdanje življenje II, Ljubljana, ARX 1997.

Musek J., Duhovna kriza, vrednote in psihologija, "Psihološka obzorja - Horizons of psychology" 3-4 (1993), p. 123-141.

Merrel F., Charles Sanders Peirce's Concept of the Sign, in: P. Cobley (ed.), The Routledge Companion to Semiotics and Linguistics, London-New York, Routledge 2001, p. 28-39.

Paladin M., Neverbalna komunikacija: Dopolniti besede in biti preprečljiv, Nova Gorica, Educa, Melior 2011. 
Pease A., Govorica telesa, Ljubljana, Mladinska knjiga 1996.

Peirce C. S., Izbrani spisi o teoriji znaka in pomena ter pragmaticizmu, Ljubljana, Krtina 2004.

Platovnjak I., Roblek J., Moliti s telesom, dušo in duhom: Molitveni priročnik, Ljubljana, Župnijski zavod Dravlje 2011.

Rush M., Decoding the secret language of your body, New York, Fireside 1994.

SC., Sacrosanctum Concilium, 1963. http://www.vatican.va/archive/hist_councils/ii_vatican_co uncil/documents/vat-ii_const_19631204_sacrosanctum-concilium_en.html(01.08.2013).

Stres A., Človek in njegov Bog, Celje, Mohorjeva družba 2007.

Šaško I., Per signa sensibilia: liturgijski simbolički govor, Zagreb, Glas Koncila 2005.

Traini S., Le due vie della semiotica: Teorie strutturali e interpretative, Milano, Strumenti Bompiani 2006.

Zagorc M., Ustvarjalno gibalna improvizacija, Ljubljana, Fakulteta za šport 2008. 